\title{
Salts from Udachnaya-East kimberlite pipe (Yakutia, Russia): occurrences and mineral composition
}

\author{
Alexander G. Polozov ${ }^{1,2}$, Sergey S. Sukhov ${ }^{3}$, Marina A. Gornova ${ }^{4}$, Svetlana N. Grishina ${ }^{5}$ \\ ${ }^{1}$ Institute of Geology of Ore Deposits RAS, Moscow, Russia, \\ ${ }^{2}$ Physycs of Geological Processes, University of Oslo, Norway, \\ ${ }^{3}$ Siberian Research Institute of Geology, Geophysics and Mineral Resource, Novosibirsk, Russia, \\ ${ }^{4}$ Institute of Geochemistry SB RAS, Irkutsk, Russia, \\ ${ }^{5}$ Institute of Geology, Mineralogy and Petrography, Novosibirsk, Russia
}

\section{Introduction}

Last years mining activity on Udachnaya-East kimberlite pipe gave us a chance to study kimberlite breccias with abundant of halides and carbonates (Sharygin et al., 2007a, b). This water-soluble assemblage occurs as breccia cement and forms chloride xenoliths of various size and composition. Olivine phenocrysts in the breccias unaffected by serpentinization include complex (carbonates + sulfates + chlorides + gas) secondary inclusions trapped at $\mathrm{P}<1 \mathrm{kbar}$ and $\mathrm{T} \leq 800^{\circ} \mathrm{C}$ (Golovin et al., 2007). Inclusions of saline melts in halite xenoliths show its high temperature water-free origin (Grishina et al., 2007). Similar $\mathrm{Sr}-\mathrm{Nd}-\mathrm{Pb}$ isotope data of salt xenoliths, groundmass silicates and groundmass water leachate imply a comagmatic origin of the chlorides with parental kimberlite magma (Kamenetsky et al., 2004, 2006; 2007a, b; Maas et al., 2005). Salts from this pipe have the same $\delta^{37} \mathrm{Cl}$ value as mantle, crust and carbonaceous chondrites (Sharp et al., 2007). By Sharygin's opinion, carbonate-chloride and chloride xenoliths could be fragments of evaporites that underwent thermometamorphism from kimberlitic melt (Sharygin et al., 2007b). Salt xenoliths occurrences and mineral composition are described insufficiently, however, and that is the target of this contribution.

\section{Geological setting}

Cambrian rocks adjacent to the Udachnaya pipe lack salts, whereas black shale and carbonate rocks are abundant. Furthermore, Devonian salts are also absent in this area (Matukhin, 1991). The Udachnaya pipe is located on the SW flank of the Cambrian DaldynMarkha carbonate bank (Sukhov, 2001). Evaporite rocks accumulated in at sabkha environment from ca. $520 \mathrm{Ma}$. Unfortunately, there is no deep drilling into inner part of bank, thus we have no direct evidence of the presence of sedimentary salts. Nevertheless, because of our reconstruction we suppose that Cambrian salts from Daldyn-Markha bank could be a potential supplier to Udachnaya pipe.

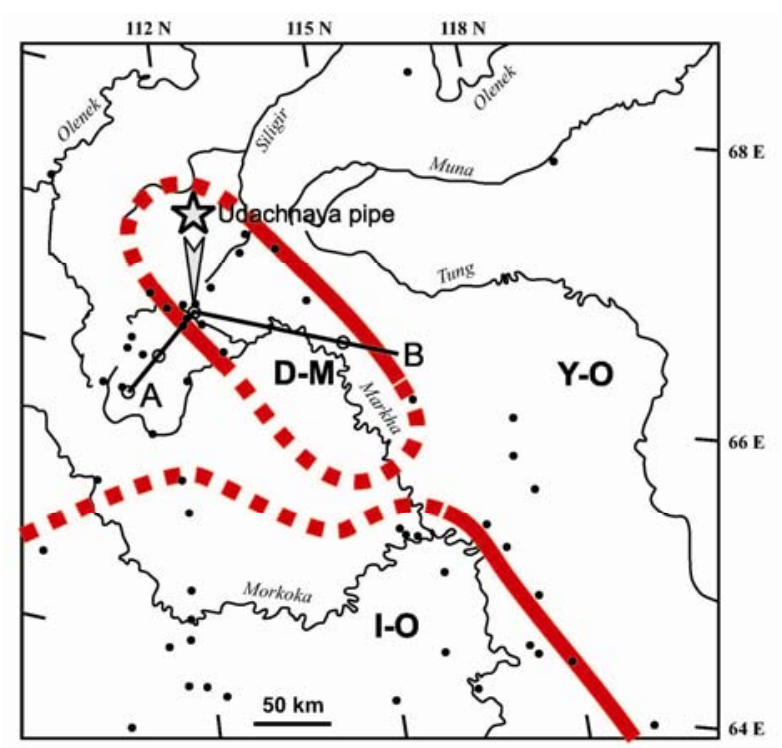

Irkutsk - Olekma (I-O) carbonate platform and Daldyn - Markha (D-M) carbonate bank conjugated with Yudom-Olenek (Y-O) basin at Late Amga (Middle Cambrian) Time. Reef margins established (solid line) and proposed (dotted line) compiled from Sukhov (2001) and Kononov et al. (2007). Dots are prospecting boreholes and A-B line is the cross-section, shown on the next fugure.

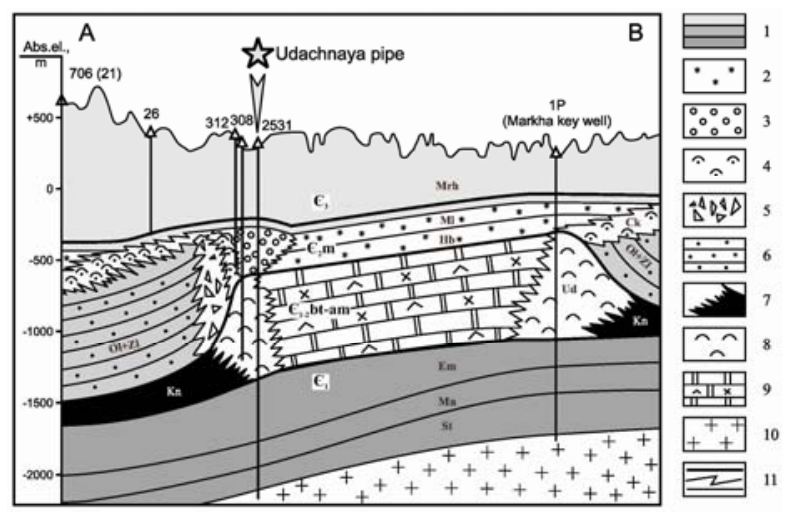


Cross-section of Daldyn-Markha bank along A-B line. Note inclined position of carbonate bank, composed by various rocks: 1 - Cambrian and Ediacarian carbonates; 2 - sabkha; 3 - carbonate bar deposits; 4 terrigenous-carbonate rocks (marls); $5-$ dolomite breccias; 6 - carbonate-terrigenous rocks; 7 - black shales; 8 - reef rocks; 9 - lagoon sulfate-saltcarbonates rocks and 10 - granite-gneiss basement; 11 - time (thick), facial (zigzag) and geological (thin) lines. Time interval of sedimentary rocks span Ediacarian and Cambrian.

\section{Occurrence of salts in Udachnaya-East pipe}

Salts in pipe occur as groundmass cement, phenocrysts vuggs, veins, cutting mantle xenoliths, and as xenoliths $(a-h)$. Xenoliths size varies from $\mathrm{cm}(e, f)$ to $0.5 \mathrm{~m}(\mathrm{a})$. They have various angularity and surfaces (a,c), corroded by both surface water (c) and kimberlite melt (e). Big xenoliths have clear rims that contain pale to deep blue halite crystals $(b, d)$. Smaller xenoliths compose of predominantly blue halite. Carbonatehalides xenoliths compose of tabular carbonates, interstitial halides, and some minor minerals $(\mathrm{g}, \mathrm{h})$.

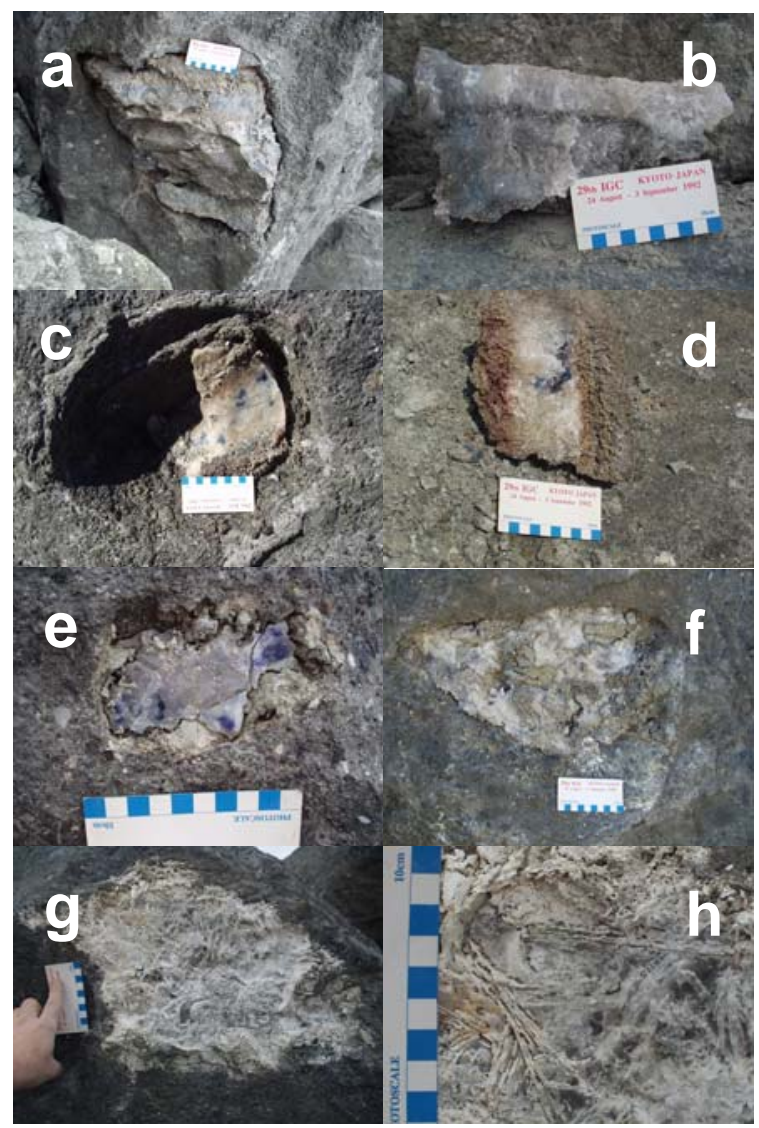

Samples List (SL). Salts henoliths with various size, angularity (a,c,e,f), mineral composition (a,c,e,f,g,h) and presence of pale to deep blue halite $(b, c, d, e)$ originated from thermal metamorphism of salt xenolths.

\section{Salt xenoliths composition}

We studied minerals with electron microprobe, SEMEDS, and XRD. Mineral associations of cores include silicates, carbonates and sulfates of both sedimentary and metamorphic origins. Host halite in cores retains rare chevron-like pattern of fluid inclusions. Mineral associations of rims include silicates, carbonates and sulfates with evidence for metamorphic overprint and possibly melting. Xenolith rim halite contains abundant elongated sylvite inclusions. Carbonate-halides xenolith contains halite-sylvite mixtures, silicates (e.g. monticellite) and rare carbonates (e.g. shortite).

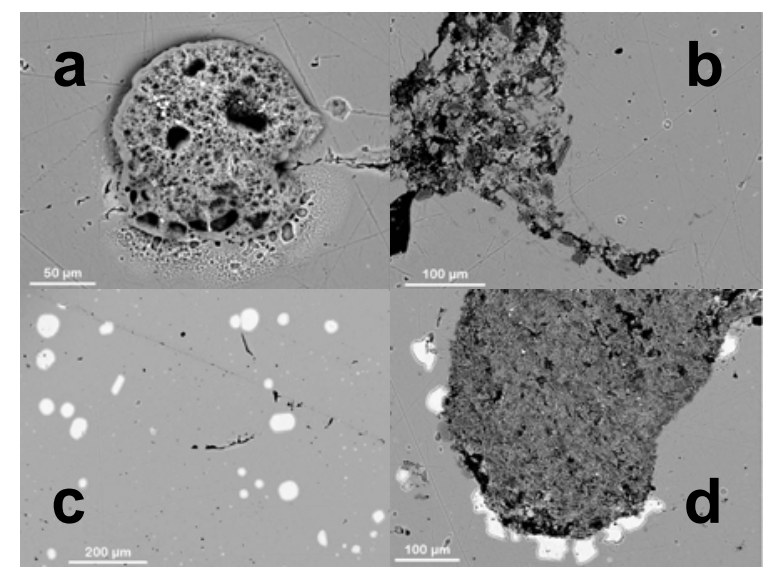

Salt xenoliths. Inclusions of $\mathrm{CaCl}_{2}$ (a) and pelitic sedimentary clasts (b) from central part of salt xenolith (c,d of SL). Later comprise of small crystals of anhydrite and hydrosilicates(?).

Round sylvite inclusions (c) and metamorphised pelitic clasts (d) from redish rim zone of xenolith (c,d of SL). Later comprise of rare zircon, magnetite, ilmenite, feldspar and hayuine.

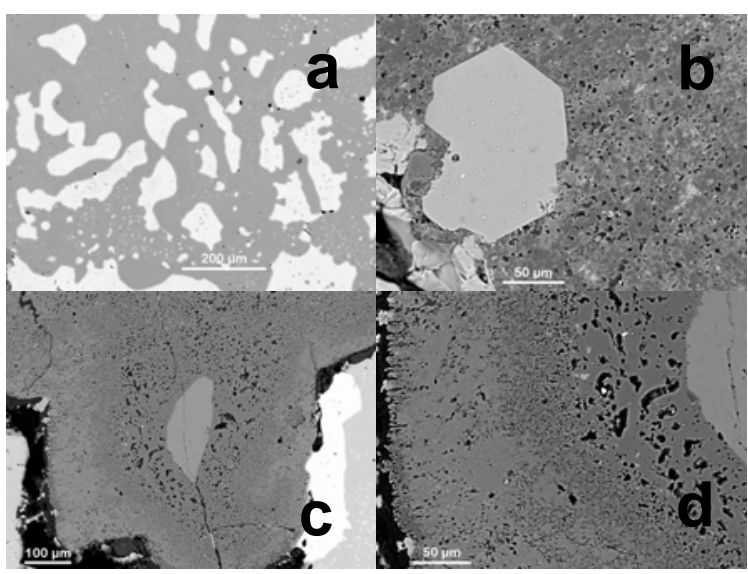

Carbonate-halide xenoliths. Complex intergrowing of white sylvite and grey halite (a) from intergranular infilling of carbonate minerals from ( $\mathrm{g}, \mathrm{h}$ of SL) and monticellite (b) from silicate-carbonate aggregates. Complex history of calcite transformation $(\mathrm{c}, \mathrm{d})$ from the same type of xenoliths ( $\mathrm{g}$,h of SL). 


\section{Conclusion}

Metamorphosed and melted salts impregnate kimberlite groundmass, resulting in an apparent magmatic origin. Our results demonstrate of sedimentary origin of salt xenoliths from Udachnaya-East pipe.

\section{References}

Golovin, A. N., Sharygin, V. V. and Pokhilenko, N. P. 2007. Melt Inclusions in Olivine Phenocrysts in Unaltered Kimberlites from the Udachnaya-East Pipe, Yakutia: Some Aspects of Kimberlite Magma Evolution during Late Crystallization Stages. Petrology, 15, 168-183.

Grishina, S., Polozov, A., Titov, A. and Goryainov, S. 2007. Inclusions of saline melts in halite from chloride xenoliths of Udachnaya-East kimberlite, Siberia. ECROFI-XIX Abstract Volume, 76.

Kamenetsky, M. B., Sobolev, A. V., Kamenetsky, V. S., Maas, R., Danyushevsky, L. V., Thomas, R., Pokhilenko, N. P. and Sobolev, N. V., 2004. Kimberlite melts rich in alkali chlorides and carbonates: A potent metasomatic agent in the mantle. Geology, 32, 845-848.

Kamenetsky, V. S., Kamenetskaya, M. B., Sharygin, V. V. and Golovin, A. N. 2007b. Carbonate-chloride enrichment in fresh kimberlites of the UdachnayaEast pipe, Siberia: A clue to physical properties of kimberlite magmas? Geophysical Research Letter, 343, L09316.

Kamenetsky, V. S., Kamenetskaya, M. B., Sharygin, V. V., Faure, K. and Golovin, A. N. 2007a. Chloride and carbonate immiscible liquids at the closure of the kimberlite magma evolution (Udachnaya-East kimberlite, Siberia). Chemical Geology, 237, 384400.

Kamenetsky, V. S., Sharygin, V. V., Kamenetskaya, M. B. and Golovin, A. N. 2006. Chloride-Carbonate Nodules in Kimberlites from the Udachnaya Pipe: Alternative Approach to the Evolution of Kimberlite Magmas. Geochemistry International, 44, 935-940.
Kononov, A. M., Alekseev, S. V., Sukhov, S. S. and Alekseeva, L.P. 2007. Peculiarity of cryolithozone formation on the SW flank of Olenek cryoartezian basin. Hydrogeochemistry of sedimentary basins. Proceedings of Russian Scientific Conference. Tomsk, 263-269. (in Russian)

Maas, R., Kamenetsky, M. B., Sobolev, A. V., Kamenetsky, V. S. and Sobolev, N. V., 2005. Sr, Nd, and $\mathrm{Pb}$ isotope evidence for a mantle origin of alkali chlorides and carbonates in the Udachnaya kimberlite, Siberia. Geology, 33, 549-552.

Matukhin, R.G. 1991. Devonian and Lower Carboniferous of the Siberian craton (composition, conditions of sedimentation, ore potential). Novosibirsk. Siberian Branch of Nauka Publisher. 164 p. (in Russian)

Sharp, Z. D., Barnes, J. D., Brearley, A. J., Chaussidon, M. T., Fischer, P. and Kamenetsky, V. S. 2007. Chlorine isotope homogeneity of the mantle, crust and carbonaceous chondrites. Nature, 446, 10621065.

Sharygin, V. V., Golovin, A. N., Pokhilenko, N. P. and Kamenetsky, V. S., 2007b. Djerfisherite in the Udachnaya-East pipe kimberlites (SakhaYakutia,Russia): paragenesis, composition and origin. European Journal of Mineralogy, 19, 51-63.

Sharygin, V. V., Kamenetsky, V. S., Kamenetskaya, M. B., Seretkin, Yu. V. and Pokhilenko, N. P. 2007a. Rasvumite from the Udachnaya-East Pipe: The First Finding in Kimberlites. Doklady Earth Sciences, 415A, 929-934.

Sukhov, S.S. 2001. Facies and stratigraphic model of DaldynMarkha bank: illustration to accumulation mechanism of carbonate deposits on the Siberian craton. Lithology and oil-and-gas potential of carbonate deposits. Proceedings of 2nd All-Russian Lithologic Conference and 8th All-Russian Symposium on fossilized corals and reefs. Syktyvkar, 237-239. (in Russian) 